với tỷ lệ khỏi bệnh cao, thời gian nghỉ dưỡng ngắn, ít tác dụng không mong muốn. Tuy nhiên, cần thời gian theo dõi dài hơn để đánh giá tỷ lệ tái phát sau điều trị.

\section{TÀI LIỆU THAM KHẢO}

1. Trướng Văn Huân (2013). Nghiên cứu đặc điểm lâm sàng, các yếu tổ liên quan và kết quả điều trị hat cơm phẳng bằng laser $\mathrm{CO} 2$.

2. Eliliot J. Androphy and Reinhard Kirnbauer (2012). Human papilloma virus infections.
Fitzpatricks Dermatology in General Medicine. 8th

3. Grillo E., Boixeda P., Ballester A., et al. (2014). Pulsed dye laser treatment for facial flat warts. Dermatol Ther, 27(1).

4. Khandpur S. and Sharma V.K. (2008). Efficacy of pulsed dye laser in cosmetically distressing facial dermatoses in skin types iv and v. Indian J Dermatol, 53(4), 186-189.

5. Vargas H., Hove C.R., Dupree M.L., et al. (2002). The treatment of facial verrucae with the pulsed dye laser. The Laryngoscope, 112(9), 1573-1576.

\title{
ĐĂC ĐIỂM LÂM SÀNG, HÌNH ẢNH HỌC VÀ KẾT QUẢ ĐIỀU TRI NHỒI MÁU NÃO CẤP Ở NGƯỜI TRẺ TUỔI TẠI BỆNH VIÊ̂N BẠCH MAI
}

\author{
Hoàng Trọng Tuệ, Mai Duy Tôn ${ }^{2}$, Nguyễn Anh Tuấn², Đào Việt Phương ${ }^{2}$
}

\section{TÓM TẮT}

Mục tiêu: Tìm hiểu đặc điểm lâm sàng, hình ảnh học vă kết quả điều trị nhồi máu não cấp ở người 18 45 tuổi tai bệnh viện Bach Mai. Phương pháp nghiên cứu: Nighiên cứu mô tả cắt ngang. Đối tượng nghiên cứu là những bệnh nhân được chẩn đoán xác định nhồi máu não cấp, trong độ tuối từ $18-45$, điều trị tại trung tâm cấp cứu $A 9$ và trung tâm đột quy. Bệnh viện Bạch Mai từ tháng 11/2019 đến tháng 6/2021, theo dõi kết cục lâm sàng sau khi ra viện 90 ngày. Kết quả: Tổng số đối tượng nghiên cứu là 91 bệnh nhân, trong đó nam giới chiểm tỉ lệ $69,2 \%$ cao hớn nữ giới 30,8\%. Tuổi trung, bình: 37,62 (SD: \pm $5,83)$, nhóm tuổi từ 40 - 45 tuổi chiếm tî lệ lớn nhất $49,4 \%$, nhóm tuổi $18-29$ tuổi chiếm tỉ lệ thấp nhất $8,8 \%$. Số bệnh nhân nhập viện trong vòng 3 giờ đầu sau khởi phát chiếm $23,1 \%$, sau 3 giớ - 4,5 giớ chiếm $6,6 \%, 4,5$ giờ -6 giờ $16,5 \%$, số bệnh nhân nhập viện sau 6 giờ chiếm tî lệ cao nhất $53,8 \%$. Trong các yểu tố nguy cớ, thường gặp nhất là tăng huyết áp và rối loạn chuyển hóa lipid iần lượt là $19,8 \%$ và $24,2 \%$, đái tháo đường $3,3 \%$, rung nhî̉ chiếm $11 \%$, thữa cân là $12,2 \%$. Phân loại theo TOAST, nguyên nhân bệnh mạch máu lớn chiếm tỉ lệ cao nhất $31,9 \%$, nguyên nhân mạch máu nhỏ chiếm $23,1 \%$, thuyên tắc mạch từ tim chiếm 14,3\%; 19,8\% nguyên nhân không xác định, 10,9\% nguyên nhân xác định khác. Tại thời điểm ra viện, 56,1\% bênh nhân có kết cục thần kinh tốt điểm mRS $0-1$, số bệnh nhân có kết quả không tốt điểm mRS 2-6 chiếm 43,9\%. Sau 90 ngày, bệnh nhân có điểm mRS $0-1$ chiếm 79,1\%, tăng gấp 1,8 lần. Kết luận: Kết quả điều trị bệnh nhân đột quy nhồi máu não người trẻ tại bệnh việ̂n Bạch Mai có tî̉ lệ hồi phục tốt ở cả nhóm điều trị can thiệp và điêu trị nội khoa đơn thuần.

\footnotetext{
${ }^{1}$ Bệnh viện đa khoa Hà Đông

${ }^{2}$ Bềnh viền Bach Mai

Chịu trách nhiệm chính: Hoàng Trọng Tuệ

Email: hoangtt.ajax@gmail.com

Ngày nhận bài: 9.8.2021

Ngày phản biện khoa học: 30.9.2021

Ngày duyệt bài: 11.10.2021
}

Tư khoá: Đột quy. nhồi máu não cấp, người trẻ, kết quả điều trị

\section{SUMMARY \\ CLINICAL CHARACTERISTICS, RADIOLOGICAL FEATURES AND TREATMENT OUTCOME OF ACUTE ISCHEMIC STROKE IN YOUNG ADULTS AT THE BACH MAI HOSPITAL}

Objectives: Clinical characteristics, radiological features and treatment outcome of acute ischemic stroke in young adults ( 18 - 45 years) at the Bach Mai hospital. Methods: This study retrospectively reviewed the records of all 18 to 45 -year-old patients who were admitted to the Emergency Department and Stroke center of Bach Mai hospital from November 2019 to June 2021. The three months clinical outcome was evaluated using the modified Rankin scale (mRS) score. The mRS score was used to classify clinical outcome as favourable (score $0-1$ ) or unfavourable (score 2-6). Results: There were 91 patients, 63 men $(69.8 \%)$ and 29 women: with a mean age of $37.62 \pm 5.83$ years (range 18-45 years). Stroke of large-artery atherosclerosis $31.9 \%$ was the most common subtype, whereas other determined etiology (10.9\%). Among all the patients, 42 (46.2\%) arrived at hospital within 6 hours of stroke onset, and the number of patients who were admitted to hospital $>6$ hours after stroke onset, $49(53.8 \%)$. In the survey of risk factors, the common risk factors were hyperlipidemia $24.2 \%$, hypertension $19.8 \%$, overweight $12.2 \%$, atrial fibrillation $11 \%$, diabetes mellitus $3.3 \%$. At three months hospital discharge, favorable (mRS:0-1) and unfavorable outcomes (mRS $2-6)$ had incidences of $79.1 \%$ and $20.9 \%$, respectively, mortality was $5.5 \%$. Conclusions: Our study found that ischemic stroke of young adults patients at Bach Mai hospital had a good outcome at three months hospital discharge.

Keywords: Acute ischemic stroke, young adult, outcome.

\section{I. ĐặT VẤN ĐỀ}

Đột quỵ não là một trong những vấn đề y tế 
lớn trên toàn cầu, là nguyên nhân thứ 2 gây tử vong và thứ 3 gây tàn tật trên toàn thế giới, nguyên nhân thứ 5 gây tàn tật và tử vong ở người trẻ ${ }^{1}$. Đột quy do thiếu máu não cục bộ không còn là căn bệnh chỉ ảnh hưởng đến người cao tuổi. Một phần tư đột quy. do thiếu máu cục bộ xảy ra ở những người trong độ tuổi lao động ở các nước thu nhập cao, số người trẻ tuổi mổi năm mắc đột quy mới khoảng 3,6 triệu người ${ }^{2}$.

Những nghiên cứu gần đây ở Mỹ, Châu Âu cũng như ở Châu Á chỉ ra tỉ lệ nhồi máu não ở người trẻ đang tăng và các yếu tố nguy cơ truyền thống thường gặp ở người già như tăng huyết áp, rối loạn mõ máu, đái tháo đường, hút thuốc và béo phì cũng thường gặp ở người trẻe ${ }^{3,4}$.

Ngày nay, những tiến bộ về khoa học kĩ thuật trong chẩn đoán hình ảnh cũng như sự phát triển về chẩn đoán và điều trị nhồi máu nã̃o như tiêu sợi huyết, lấy huyết khối cơ học, cùng với việc hình thành các đơn vị đột quyy, phục hồi chức năng... đã đóng vai trò quan trọng tác động đến kết quả điều trị nhồi máu não. Tuy vậy những nghiên cứu về lâm sàng cũng như đánh giá kết quả điều trị ở nhóm bệnh nhân trẻ tuổi còn chưa nhiều, do đó chúng tôi tiến hành nghiên cứu: "Đặc điểm lâm sàng, hình ảnh học và kết quả điều trị nhồi máu não cấp ở người 18 - 45 tuôi tại bệnh viện Bạch Mai". Mục tiêu nghiên cứu:

Tìm hiểu đặc điểm lâm sàng, hình ảnh học và kêt quả điều trị nhồi máu não cấp ở người 18 45 tuổi tại bệnh viện Bạch Mai.

\section{II. ĐỐI TƯợNG VÀ PHƯƠNG PHÁP NGHIÊN CỨU}

1. Đối tượng nghiên cứu: Bệnh nhân được chẩn đoán xác định nhồi máu não dựa vào định nghĩa Đột quỵ nã̃o của Tổ chức y tế thế giới, có độ tuổi từ 18 - 45 tuổi trong thời gian từ tháng 11/2019 đến tháng 6/2021.

\section{Tiêu chí loại trừ}

- Bệnh nhân có tiền sử chấn thương sọ não

- Bệnh án nghiên cứu không đủ thông tin.

\section{Phương pháp nghiên cứu:}

Thiết kế nghiên cứu: Nghiên cứu mô tả cắt ngang.

Địa điểm nghiên cứu: tại Trung tâm cấp cứu, Trung tâm đột quỵ. Bệnh viện Bạch Mai.

Phương pháp chọn mẩu: chọn mẫu thuận tiện. Chọn các hồ sở bệnh án bệnh nhân được chẩn đoán: Đột quy nhồi máu não cấp tính, tuổi từ 18 - 45 tuổi, điều trị tại Trung tâm cấp cứu, Trung tâm đột quy Bệnh viện Bạch Mai trong thời gian từ tháng 11/2019 đến tháng 6/2021.

Việc thu thập số liệu dựa trên mẫu bệnh án nghiên cứu. Kết cục lâm sàng được đánh giá bằng thang điểm mRS 90 ngày sau ra viện được thu thập bằng gọi điện thoại cho bệnh nhẩn hoặc người thân của bệnh nhân.

3. Xử lý số liệu: Theo phương pháp thống kê y học, sử dụng phần mềm SPSS 20.0 để phân tích số liệu.

\section{KẾT QUẢ NGHIÊN CỨU}

Trong thời gian từ tháng 11 năm 2019 tới tháng 06 năm 2021, chúng tôi thu thập được 91 bệnh án có đủ tiêu chuẩn tham gia vào nghiên cứu.

\section{1. Đăc điểm lâm sàng}

3.1.1. Đặc điểm chung và đặc điểm lâm sàng lúc vào viện

Bảng 1. Phân bố tuổi của nhóm nghiên cứu

\begin{tabular}{|c|c|c|c|}
\hline \multicolumn{2}{|c|}{ Đặc điểm } & $\begin{array}{c}\text { Tân số } \\
(\mathbf{n = 9 1 )}\end{array}$ & $\begin{array}{c}\text { Tỉ lệ } \\
(\mathbf{\%})\end{array}$ \\
\hline \multirow{4}{*}{ Tuổi } & $18-25$ & 3 & 3,3 \\
\cline { 2 - 4 } & $26-35$ & 24 & 26,4 \\
\cline { 2 - 4 } & $36-45$ & 64 & 70,3 \\
\cline { 2 - 4 } & $\bar{X} \pm$ SD & $37,62 \pm 5,83$ \\
\hline \multirow{2}{*}{ Giới } & Nam & 63 & 69,2 \\
\cline { 2 - 4 } tính & Nữ & 28 & 30,8 \\
\hline
\end{tabular}

Nhân xét: Tuổi trung bình: $37,62 \pm 5,83$, nhỏ tuổi nhất 19, lớn tuổi nhất là 45. Trong đó nhóm tuổi từ 36 - 45 tuổi chiếm tỉ lẹ lớn nhất $70,3 \%$, nhóm tuổi $18-25$ tuổi chiếm tỉ lệ thấp nhất 3,3\%. Nam giới chiểm tỉ lệ $69,2 \%$, nữ giới chiếm 30,8\%.

Bảng 2. Đặc điểm tiền sử

\begin{tabular}{|c|c|c|}
\hline Tiền sử & $\begin{array}{c}\text { Tân số } \\
(\mathbf{n = 9 1 )}\end{array}$ & $\begin{array}{c}\text { Tỉ lệ } \\
(\mathbf{\%})\end{array}$ \\
\hline Tăng huyết áp & 13 & 14,3 \\
\hline Đái tháo đường & 3 & 3,3 \\
\hline Rung nhĩ & 7 & 7,7 \\
\hline RLCH lipid & 4 & 4,4 \\
\hline Lupus & 2 & 2,2 \\
\hline NMN cũ & 6 & 6,6 \\
\hline Bệnh Moyamoya & 1 & 1,1 \\
\hline Gia định có người đột quy não & 11 & 12.1 \\
\hline Hút thuỗc lá & 7 & 7,7 \\
\hline Sữ dụng chất kích thích & 3 & 3,3 \\
\hline Đau đâuu & 6 & 6,6 \\
\hline
\end{tabular}

Nhân xét: $14,3 \%$ bênh nhân có tiên sử Tăng huyết áp, 3,3\% có tiền sử đái tháo đường; $7,7 \%$ có tiền sử rung nhĩ; $4,4 \%$ có tiền sử RLCH lipid, $6,6 \%$ có tiền sử nhồi máu não trước đó, $13,2 \%$ có người nhà bị đột quỵ não, 1 bệnh nhân $(1,1 \%)$ có tiền sử bệnh Moyamoya.

Bảng 3. Thời gian khởi phát đến khi nhập viện

\begin{tabular}{|l|l|l|}
\hline Khoảng thời gian & Tân số(n=91) Tỉ lệ(\%) \\
\hline
\end{tabular}

\begin{tabular}{|c|c|c|}
\hline$\leq 3 h$ & 21 & 23,1 \\
\hline Sau $3 h-4,5 h$ & 6 & 6,6 \\
\hline
\end{tabular}




\begin{tabular}{|c|c|c|}
\hline Sau 4,5h - 6h & 15 & 16,5 \\
\hline Trên 6h & 49 & 53,8 \\
\hline Tống & 91 & 100 \\
\hline Trung bình (giờ) & \multicolumn{2}{|c|}{8,33} \\
\hline Nhân xét: Số bênh nhân nhập viện trong 3
\end{tabular}

giờ đầu chiếm 23,1\% sau 3-4 5 giờ chiếm $6,6 \%, 4,5$ - 6 giờ chiếm $16,5 \%$, sau 6 giờ chiếm tî lệ cao nhất 53,8\%.

Bảng 4. Phân bố mức độ bệnh nhân theo thang điêm NIHSS

\begin{tabular}{|c|c|c|}
\hline Mức độ & Tần số $(\mathbf{n = 9 1 )}$ & Tỉ lệ(\%) \\
\hline$\leq 7$ & 51 & 56,0 \\
\hline $8-15$ & 33 & 36,3 \\
\hline$\geq 16$ & 7 & 7,7 \\
\hline Tống & $\mathbf{9 1}$ & $\mathbf{1 0 0}$ \\
\hline NIHSS Trung bình & $7,41 \pm 5,5$ \\
\hline
\end{tabular}

Nhân xét: Điếm NIHSS trung bình là 7,41 \pm 5,5 , trong đó số bệnh nhân có mức độ nhẹ chiếm $56 \%$, trung bình chiếm 36,3; 7,7\% bệnh nhân có mức độ nă̆ng.

Bảng 5. Đặc đỉêm về yêu tố nguy cơ

\begin{tabular}{|c|c|c|}
\hline Yêu tố nguy cơ & $\begin{array}{c}\text { Tân số } \\
(\mathbf{n = 9 1 )}\end{array}$ & $\begin{array}{c}\text { Tỉ lệ } \\
(\mathbf{\%})\end{array}$ \\
\hline Tăng huyết áp & 18 & 19,8 \\
\hline Đái tháo đường & 3 & 3,3 \\
\hline Rung nhĩ & 10 & 11 \\
\hline Rối loạn chuyến hóa lipid & 22 & 24,2 \\
\hline Thừa cân & 11 & 12,1 \\
\hline
\end{tabular}

Nhân xét: Yếu tố nguy cơ thường găp nhất là tăng huyết áp và rối loạn chuyển hóa lipid lần lượt là $19,8 \%$ và $24,2 \%$, đái tháo đường $3,3 \%$, rung nhĩ chiếm 11\%, thừa cân là 12,2\%

Bảng 6. Phân bố nguyên nhân theo phân Ioại TOAST

\begin{tabular}{|c|c|c|}
\hline Nguyên nhân & $\begin{array}{c}\text { Tân số } \\
(\mathbf{n = 9 1 )}\end{array}$ & $\begin{array}{c}\text { Tỉ lệ } \\
(\mathbf{\%})\end{array}$ \\
\hline Bệnh mạch máu lớn & 29 & 31,9 \\
\hline Bệnh mạ́ch máu nhỏ & 21 & 23,1 \\
\hline Thuyên tắc mạch từ tim & 13 & 14,3 \\
\hline Không xác định & 18 & 19,8 \\
\hline Nguyên nhân xác định khác & 10 & 10,9 \\
\hline
\end{tabular}

Nhânn xét: Nguyên nhân bệnh mạch máu lớn chiếm tỉ lê cao nhất $31,9 \%$, nguyên nhân mach máu nhỏ chiếm 23,1\%, thuyên tắc mạch từ tim chiếm 14,3\%; 19,8\% nguyên nhân không xác định, 10,9\% nguyên nhân xác định khác.

3.2. Đặc điểm hình ảnh học

Bảng 7. Phân bố vị trí tắc mạch

\begin{tabular}{|c|c|c|}
\hline Vị trí & $\begin{array}{c}\text { Tân số } \\
(\mathbf{n = 9 1 )}\end{array}$ & $\begin{array}{c}\text { Tỉ lệ̂ } \\
\text { (\%) }\end{array}$ \\
\hline Không tắc mạch lớn & 39 & 42,8 \\
\hline $\begin{array}{c}\text { Tắc động mạch não giữa } \\
\text { đoạn M1 }\end{array}$ & 23 & 25,3 \\
\hline $\begin{array}{c}\text { Tắc động mạch não giữa } \\
\text { đoạn M2 }\end{array}$ & 9 & 9,9 \\
\hline
\end{tabular}

\begin{tabular}{|c|c|c|}
\hline Tắc động mạc cảnh trong & 16 & 17,6 \\
\hline Tắc động mạch thân nền & 4 & 4,4 \\
\hline
\end{tabular}

Nhân xét; Về hình ảnh học, 42,8\% bệnh nhân không có tắc mạch lớn chiểm tỉ lê cao nhất, số bệnh nhân tắc động mạch não giữa đoạn $M 1$ và $M 2$ lân lượt là $25,3 \%$ và 9,9\%, 17,6\% bênh nhân tắc động mạch cảnh trong, 4,4\% tắc động mạch thân nền.

\subsection{Kết quả điêu trị}

\section{Bảng 8. Phương pháp điều tri}

\begin{tabular}{|c|c|c|}
\hline Phương pháp điêuu trị & $\begin{array}{c}\text { Tân số } \\
(\mathbf{n = 9 1 )}\end{array}$ & $\begin{array}{c}\text { Tí lệ } \\
(\mathbf{\%})\end{array}$ \\
\hline Tiêu sợi huyết & 9 & 9.9 \\
\hline Lấy huyết khối cớ học & 17 & 18.7 \\
\hline $\begin{array}{c}\text { Tiêu sợi huyết và lấy } \\
\text { huyết khối cơ học }\end{array}$ & 4 & 4.4 \\
\hline Nội khoa & 61 & 67.0 \\
\hline
\end{tabular}

Nhận xét: Số bệnh nhân sử dụng phương pháp tiêu sợi huyết đường tĩnh mạch chiếm $9.9 \%, 18,7 \%$ trường hợp lấy huyết khối cơ học, kết hợp tiêu sợi huyết và lây huyết khối cơ học chiếm $4,4 \%$, số bệnh nhân điều trị nội khoa chiếm $67,0 \%$.

Bảng 9. Kêt cục lâm sàng theo thang điểm mRS sau 90 ngày

\begin{tabular}{|c|c|c|c|c|}
\hline \multirow{2}{*}{$\begin{array}{c}\text { Điểm } \\
\text { mRS }\end{array}$} & \multicolumn{2}{|c|}{$\begin{array}{c}\text { Thời điếm ra } \\
\text { viện }\end{array}$} & \multicolumn{2}{c|}{ Sau 90 ngày } \\
\cline { 2 - 5 } & Tân số & $\begin{array}{c}\text { Tí lệ } \\
(\mathbf{\%})\end{array}$ & Tân số & $\begin{array}{c}\text { Tí lệ } \\
(\mathbf{\%})\end{array}$ \\
\hline 0 & 7 & 7,7 & 49 & 53,8 \\
\hline 1 & 44 & 48,3 & 23 & 25,3 \\
\hline 2 & 12 & 13,2 & 6 & 6,6 \\
\hline 3 & 13 & 14,3 & 6 & 6,6 \\
\hline 4 & 7 & 7,7 & 1 & 1,1 \\
\hline 5 & 7 & 7,7 & 1 & 1.1 \\
\hline 6 & 1 & 1,1 & 5 & 5.5 \\
\hline
\end{tabular}

Nhânn xét: Sau 90 ngày số bệnh nhân có thể hoạt động độc lập có điểm mRS từ 0 -1 chiếm tỉ lệ $79,1 \%$, số bệnh nhân có kết quả không tốt mRS 2-6 điểm chiếm tỉ lệ 20.9\%. Tỉ lệ tử vong là $5.5 \%$.

Bảng 10. Ảnh hưởng của một số đặc điểm chung tới kêt quả điều trị

\begin{tabular}{|c|c|c|c|c|c|}
\hline & \multicolumn{2}{|c|}{ mRS } & \multirow{2}{*}{ OR } & \multirow[b]{2}{*}{$\mathbf{p}$} \\
\hline & & $0-1$ & $2-6$ & & \\
\hline \multirow{2}{*}{ Tuổi } & $\leq 35$ & $\begin{array}{c}24 \\
88.9 \%\end{array}$ & $\begin{array}{c}3 \\
11.1 \%\end{array}$ & 1 & \multirow[b]{2}{*}{$\begin{array}{l}0,1 \\
67\end{array}$} \\
\hline & $\begin{array}{c}36- \\
45\end{array}$ & $\begin{array}{c}48 \\
75.0 \%\end{array}$ & $\begin{array}{c}16 \\
25.0 \%\end{array}$ & $\begin{array}{c}2,67(0,71 \\
-10,05)\end{array}$ & \\
\hline \multirow{2}{*}{$\begin{array}{l}\text { Giới } \\
\text { tính }\end{array}$} & Nam & $\begin{array}{c}53 \\
84.1 \% \\
\end{array}$ & $\begin{array}{c}10 \\
15.9 \%\end{array}$ & 1 & \multirow[b]{2}{*}{$\begin{array}{l}0,0 \\
97\end{array}$} \\
\hline & Nữ & $\begin{array}{c}19 \\
67.9 \%\end{array}$ & $\begin{array}{c}9 \\
32.1 \%\end{array}$ & $\begin{array}{r}2,51(0,89 \\
-\quad 7,12)\end{array}$ & \\
\hline
\end{tabular}

Nhân xét: Không có sự khác biệt về kết cục điều trị ở nhóm tuổi dưới 36 và từ 36 - 45 tuổi 
về kết cục điều trị $(p>0,05)$. Không có sự khác biệt về kết cục điều trị giữa 2 giới sau 3 tháng ( $p$ $>0,05$ ).

Bảng 11. Ánh hưởng của điểm NIHSS ban đâuu tới kết cục sau 3 tháng

\begin{tabular}{|c|c|c|c|c|}
\hline \multirow{2}{*}{$\begin{array}{c}\text { Điểm } \\
\text { NIHSS }\end{array}$} & \multicolumn{2}{|c|}{ mRS } & \multirow[t]{2}{*}{ OR } & \multirow[b]{2}{*}{$\mathbf{p}$} \\
\hline & $0-1$ & $2-6$ & & \\
\hline$<8$ & $\begin{array}{c}48 \\
94.1 \% \\
\end{array}$ & $\begin{array}{c}3 \\
5.9 \% \\
\end{array}$ & 1 & \\
\hline 8 & $\begin{array}{c}15 \\
55.6 \% \\
\end{array}$ & $\begin{array}{c}12 \\
44.4 \% \\
\end{array}$ & $\begin{array}{c}12,8(3,18- \\
51,57) \\
\end{array}$ & 0,0 \\
\hline 7 & $\begin{array}{c}3 \\
50.0 \%\end{array}$ & $\begin{array}{c}3 \\
50.0 \%\end{array}$ & $\begin{array}{c}16(2,21- \\
115,92)\end{array}$ & 0,0 \\
\hline
\end{tabular}

Nhân xét: Nhóm bênh nhân có điếm NIHSS ban đầu nhỏ hơn 8 có ảnh hưởng tới kết cục tốt hơn so với nhóm bệnh nhân có điểm NIHSS từ 8 - 15 điểm và trên 15 điểm với $p<0,05$

Bảng 12. Ánh hưởng của vị trí tắc mạch tới kêt cục sau 3 tháng

\begin{tabular}{|c|c|c|c|c|}
\hline \multirow{2}{*}{$\begin{array}{c}\text { Vị trí tắc } \\
\text { mach }\end{array}$} & $0-1$ & $2-6$ & OR & m \\
\cline { 2 - 3 } $\begin{array}{c}\text { Không tắc } \\
\text { mạch lớn }\end{array}$ & $\begin{array}{c}36 \\
92.3 \%\end{array}$ & $\begin{array}{c}3 \\
7.7 \%\end{array}$ & 1 & \\
\hline $\begin{array}{c}\text { Tắc Mạch } \\
\text { lớn }\end{array}$ & $\begin{array}{c}36 \\
69,2 \%\end{array}$ & $\begin{array}{c}16 \\
30,8 \%\end{array}$ & $\begin{array}{c}5,33(1,43 \\
-19,90)\end{array}$ & 0,009 \\
\hline
\end{tabular}

Nhân xét: nhóm bệnh nhân không tắc mạch lớn có ảnh hưởng tới kết cục tốt hơn nhóm bệnh nhân tắc mạch lớn $(p<0,05)$.

\section{BÀN LUÂN}

4.1 Đặc điểm của bệnh nhân. Hơn $2 / 3$ đối tượng nghiên cứu là nam giới $(69,2 \%)$, tuổi trung bình là $37,62 \pm 5,83$. Kết quả nghiên cứu tương đồng với nghiên cứu Tsong-Hai Lee (Đài Loan) tỉ lệ nam giới chiếm $71,2 \%$ và Won-Bin Park (Hàn Quốc) tuổi trung bình là 38,5 6,3

Nhóm bệnh nhân có thời gian khởi phát đến thời điểm nhập viện < 6 giờ chiếm 46,2\% cao hơn so với nghiên cứu của Won-Bin Park $(41,8 \%)$.

Tăng huyết áp và rối loạn chuyển hóa lipid là yếu tố nguy cơ thường gặp nhất, lần lượt là $19,8 \%$ và $24,2 \%$, tỉ lệ đái tháo đường chiếm $3,3 \%$, rung nhĩ chiếm $11 \%$, thừa cân chiếm $12,2 \%$. Tỉ lệ có yếu tố nguy cơ tăng huyết áp, rối loạn chuyển hoá lipid cao hơn so với nghiên cứu của tác giả Won-Bin Park (18\% và $2,6 \%)$ tuy nhiên bệnh nhân có yếu tố nguy cơ là đái tháo đường chiếm tỉ lệ thấp hơn (7,8\%).

Điểm NIHSS trung bình của đối tượng nghiên cứu là 7,41 $\pm 5,5$, trong đó số bệnh nhân có mức độ nhẹ chiếm $56 \%$, trung bình chiếm 36,3\%, 7,7\% bệnh nhân có mức độ nặng.

Phân loại nguyên nhân theo TOAST của đối tượng nghiên cứu, nhóm nguyên nhân mạch máu lớn chiếm tỉ lệ cao nhất $31,9 \%$, nguyên nhân mạch máu nhỏ chiếm $23,1 \%$, thuyên tắc mạch từ tim chiếm 14,3\%, 10,9\% nguyên nhân không xác định. Nghiên cứu Kwon SU (Hàn Quốc) cho kết quả nguyên nhân mạch máu lớn chiếm 20,8\%, mạch máu nhỏ chiếm 17,4\%, thuyên tắc mạch từ tim chiếm $18,1 \%$, nguyên nhân xác định khác $26,8 \%$, không xác định chiếm $16,8 \%{ }^{6}$.

4.2. Đặc điểm hình ảnh học. Về hình ảnh học vị trí tắc mạch não có $42,8 \%$ bệnh nhân không tắc mạch lớn, 35,2\% tắc động mạch não giữa, $17,6 \%$ tắc động mạch cảnh trong và $4,4 \%$ tắc động mạch thân nền.

4.3. Kết quả điều trị. Trong nghiên cứu của chúng tôi có $33 \%$ bệnh nhân được điều trị can thiệp tái thông mạch máu trong đó $9,9 \%$ bệnh nhẩn sử dụng phương pháp tiêu sợi huyết đường tĩnh mạch, $18,7 \%$ trường hợp lấy huyết khối cơ học, 4,4\% trường hợp kết hợp tiêu sợi huyết và lấy huyết khối cơ học và $67 \%$ điều trị nội khoa.

Tại thời điểm ra viện, $56,1 \%$ bệnh nhân có kết cục thần kinh tốt điểm mRS $0-1$, số bệnh nhân có kết quả không tốt điểm mRS 2-6 chiếm $43,9 \%$. Sau 90 ngày, bệnh nhân có điểm mRS 01 chiếm $79,1 \%$, tăng gấp 1,8 lần. Không có sự khác biệt về kêt quả điêu trị giữa 2 giới và nhóm bệnh nhân dưới 36 tuổi và từ 36-45 tuổi. Nhóm bệnh nhân có điểm NIHSS < 8 có kết cục tốt hơn 12,8 lần so nhóm có điểm NIHSS 8-15 điểm $(p=0,0001)$, và tốt hơn 16 lần so với nhóm có điểm NIHSS > 15 điểm $(p=0,012)$. Bệnh nhân không tắc mạch lớn có kết cục tốt hơn 5,33 lần so với nhóm tắc mạch lớn $(p=0,009)$

\section{KẾT LUÂN}

Kết quả điều trị bệnh nhân đột quy nhồi máu não người trẻ tại bệnh viện Bạch Mai có tỉ lệ hồi phục tốt ở cả nhóm điều trị can thiệp và điều trị nội khoa đơn thuần.

\section{TÀI LIÊU THAM KHẢO}

1. Mozaffarian D et al, Heart disease and stroke statistics-2015 update: a report from the American Heart Association. ahajournals. 2015,131(4):e29-322.

2. Feigin VL et al, Update on the global burden of ischemic and hemorrhagic stroke in 1990-2013: the GBD 2013 study. Neuroepidemiology. 2015; 45:161-76.

3. Adams Jr HP, Bendixen BH, Kappelle LJ, et al. Classification of subtype of acute ischemic stroke. Definitions for use in a multicenter clinical trial. TOAST. Trial of Org 10172 in Acute Stroke Treatment. stroke. 1993; 24(1):35-41.

4. Ji R, Schwamm LH, Pervez MA, Singhal AB. Ischemic stroke and transient ischemic attack in young adults: risk factors, diagnostic yield, 
neuroimaging, and thrombolysis. JAMA neurology. 2013;70(1):51-7.

5. Kwon SU, Kim JS, Lee JH, Lee MC. Ischemic stroke in Korean young adults. Acta Neurol Scand.
2000;101:19-24.

6. Lee TH, Hsu WC, Chen CJ, Chen ST. Etiologic study of young ischemic stroke in Taiwan. Stroke. 2002;33(8):1950-1955.

\title{
LIÊN QUAN GIỮA THUỐC LÁ VÀ BỆNH UNG THƯ PHỔI
}

\author{
GS.TS. Ngô Quý Châu \\ Giám đốc chuyên môn Bệnh viện đa khoa Tâm Anh Hà Nội, \\ chủ tịch hội Hô Hấp Việt Nam
}

Ung thư phổi là căn bệnh có tỷ lệ mắc và tử vong hàng đầu trong số các bệnh ung thư ở cả hai giới. Theo điều tra của Tồ chức nghiên cứu toàn cầu về ung thư (GLOBOCAN) năm 2020 thì số ca mắc mới ung thư phổi trong một năm là 2.206.771 đứng thứ hai chỉ sau ung thư vú và số ca tử vong trong một năm vì ung thư phổi là 1.796.144 đứng ở vị trí hàng đầu trong tử vong vì ung thư.

Hút thuốc lá là nguyên nhân chủ yếu gây ung thư phổi, cứ 10 ca mắc ung thư phổi thì có $9 \mathrm{ca}$ là có liên quan đến hút thuốc lá.
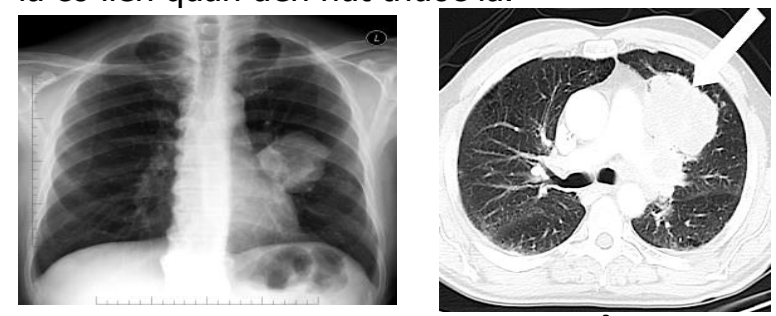

Hình 1. Hình ảnh khôii u phổi trái

Các phân tích hóa học cho thây trong khói thuốc lá tồn tai trên 7000 loai hóa chất tồn tai dưới hai dạng: dạng hạt và dạng khí. Nhiều thực nghiệm trền súc vật đã chứng minh thành phần hạt của khói thuốc lá là chất gây ung thư ở đường hô hấp và các tổ chức khác. Có 69 chất trong khói thuốc lá đã được chứng minh là nguyên nhân gây ung thư, chủ yếu là các chất thơm có vòng như Benzopyren, nitrosamin, arsenic, nickel, chrom các đồng vị phóng xạ... Các chất này tác động lên niêm mạc đường hô hấp gây nên tình trạng viêm mạn tính, phá hủy tổ chức và biến đổi tế bào dẫn đến ác tính hóa.

Các bằng chứng khoa học từ giữa thế kỷ 20 đã cho thấy mối liên quan đáng kể giữa hút thuốc lá chủ động và ung thư phổi. Nghiên cứu của Doll và Hill năm 1954 ở Anh cho thấy những người hút thuốc lá có nguy cơ bị ung thư phổi cao gấp 14 lần so với người không hút thuốc lá. Năm 1986, cơ quan nghiên cứu quốc tế về ung thư khi nghiên cứu mối quan hê giữa thuốc lá và ung thư đã đưa ra kết luận hút thuốc là nguyên nhân nổi bật của ung thư phổi trên toàn thế giới. Không chỉ hút thuốc lá chủ động mà hút thuốc thụ động cũng gây ung thư phổi ở những người lớn chưa bao giờ hút thuốc. Việc phơi nhiễm với khói thuốc ở nhà hoăc nơi làm viêc làm tăng nguy cơ ung thư phổi lển 20-30\%. Mỗi năm hút thuốc lá thụ động gây ra hơn 7300 trường hợp tử vong do ung thư phổi ở người không hút thuốc tại Mỹ.

Nguy cơ phát triển ung thư phổi gia tăng với thời gian hút thuốc lá và số lượng thuốc lá hút hàng ngàyy. Không có ngưỡng hút thuốc mà việc phơi nhiễm không có rủi do. Các yếu tố khác có thể ảnh hưởng đến khả năng phát triển ung thư phổi ở người hút thuốc lá bao gồm tuổi bắt đầu hút thuốc, mức độ hít khói thuốc, hàm lượng nicotine và nhựa thuốc lá (tar) và việc sử dụng thuốc lá không đầu lọc. Tỷ lệ nguy cớ tương đối xuất hiện ung thư phổi giữa người hút thuốc và không hút thuốc là 15 nói chung và là 25 đối với người nghiện thuốc lá nặng. Nguy cơ tích luỹ ung thư phổi ở những người nghiện thuốc lá nặng có thể tới $30 \%$ khi so sánh với nguy cơ $1 \%$ hoặc thấp hơn ở những người không hút thuốc bao giờ.

Việc cai thuốc lá giúp giảm nguy cơ phát triển ung thư phổi so với tiếp tục hút thuốc, nguy cơ ngày càng giảm hơn khi thời gian duy trì cai thuốc càng dài. Tuy nhiên, thậm chí sau một thời gian cai thuốc dài, nguy cơ ung thư phổi ở những người đã từng hút thuốc vẫn cao hơn so với những người không bao giờ hút thuốc.

Nhiều nghiên cứu cũng đã cho thấy việc cai thuốc lá sau khi chẩn đoán ung thư phổi có liên quan với việc cải thiện sức khỏe. Trong một tổng quan hệ thống phân tích gộp, việc tiếp tục hút thuốc ở những bệnh nhân được chẩn đoán ung thư phổi giai đoạn sớm hoặc giai đoạn khu trú có liên quan với sự gia tăng nguy cơ tử vong do mọi nguyên nhân, tái phát ung thư, và sự phát triển một ung thư nguyên phát ở cơ quan khác.

Cai thuốc lá giúp giảm nguy cơ biến chứng sau phẫu thuật ung thư phổi. Một nghiên cứu đoàn hệ hồi cứu đã cho thấy tỷ lệ sống sót ở 